\title{
https://doi.org/10.52240/1857-2367.2020.2(21).14 \\ BUTĂȘIREA PRIN METODA TRADIȚIONALĂ A MURULUI ROȘU \\ (RUBUS LOGANOBACCUS L. H. BAILEY) VERSUS MICROPROPAGAREA IN VITRO
}

\author{
Alexandru MÎRZA \\ Grădina Botanică Națională (Institut) „,Al. Ciubotaru”, \\ Chișinău, Republica Moldova
}

\begin{abstract}
The rooting rate of lignified and non-lignified hybridberry cuttings was tested. The experiment was conducted both with treated (with growth regulator) and untreated cuttings, at different times of the year, to prove the much higher efficiency of in vitro multiplication of the culture as compared with traditional methods of multiplication by cuttings.
\end{abstract}

Key words: Rubus loganobaccus, hybridberry cultivars, cuttings, micropropagation, IBA.

Murul roșu (Rubus loganobaccus L.H. Bailey) este o cultură valoroasă atât din punct de vedere agroalimentar (având fructe cu calităţi gustative deosebite care pot fi consumate atât în stare proaspătă, cât și sub formă prelucrată), cât și din punct de vedere terapeutic, datorită conţinutului ridicat de vitamine și antioxidanţi ce fac să fie apreciat în calitate de produs dietetic [1,3-4].

Scopul aceastui studiu a constat în determinarea procentului de înrădăcinare a culturii de mur roșu prin butăşire tradiţională, dat fiind faptul că în Laboratorul Biotehnologie și Embriologie a GBNI au fost deja realizate studii ce țin de micropropagarea in vitro a acestei culturi, iar procentul de înrădăcinre a microbutașilor în condițiile de adaptare $e x$ vitro s-a dovedit a fi de $95-98 \%$ [2].

În studiu au fost luate 4 soiuri de mur roșu: 'Tayberry Medana', 'Tayberry Buckingham', 'Logan' și 'Lincoln Logan' care au fost multiplicate prin două tipuri de butăşiri: butași nelignificaţi și butași lignificați.

Butașii nelignificați, de 10-15 cm lungime, au fost colectați în luna iulie și au fost supuși înrădăcinării prin două metode: metodă fără hormon de stimulare a înrădăcinării și cu utilizarea IBA (acid indolilbutiric) 1,5 gr/l (timp de 24 ore). Ca substrat de înrădăcinare a fost folosit amestec de turbă cu nisip (1:1).

În cazul testării înrădăcinării butașilor lignificați, aceștia au fost colectați în perioada de toamnă (lungimea 10-15 cm), după care a fost necesară o perioadă de depozitare la rece pentru 3 săptămâni. Butașii au fost înveliți în hârtie de filtru umedă și polietilenă, apoi plasaţi în frigider la $4^{\circ} \mathrm{C}$. După perioada de depozitare la rece și după o tratare prealabilă timp de 24 ore cu soluție de IBA 1,3 gr/l., au fost plasaţi în substrat de înrădăcinare nisp/perlită (1:1).

Primele rădăcini la butașii nelignificați, au apărut după patru săptămâni, iar încă peste două săptămâni, cei înrădăcinați au fost transplantați în containere de plastic de tip P9. Ținând cont de o vară cu temperaturi ridicate, procentul de înrădăcinare a butașilor nelignificați și netratați cu stimulatori de înrădăcinare a fost de $20 \%$ iar la cei trataţi cu IBA - de 33\%.

În cazul butaşilor lignificați, primele rădăcini au apărut de asemenea după patru săptămâni de la plasarea în substrat, iar peste încă două săptămâni au fost transplantați în ghivece. Procentul de înrădăcinare al butașilor nelignificați a fost de $50 \%$. 
Astfel se constată că de pe lotul experimental de arbuști fructiferi netradiţionali al GBNI, de pe o plantă au fost prelevați doar 50 de butași, în timp ce prin multiplicarea in vitro, în dependență de capacitatea laboratorului, posibilitatea de producere este de ordinul zecilor și sutelor de mii sau chiar mai mult.

Din cele expuse denotă că micropropagarea in vitro a murului roșu în comparație cu butășirea tradițională este mult mai rapidă și în același timp independentă față de conditiiile mediului ambiant.

Cercetările au fost realizate cu suportul financiar al proiectului 20.80009.7007.14 „Cercetări privind mobilizarea diversităţii vegetale cu potenţial ornamental pentru conservarea ex-situ”.

\section{BIBLIOGRAFIE SELECTIVĂ}

1. Halvorsen B., Holte K. et al. A systematic screening of total antioxidants in dietary plants. The Journal of Nutrition, 2002, v. 132, p. 461-471.

2. Mîrza Al., Ciorchină N., Comanici I. Microclonarea și micropropagarea arbuștilor de hibrizi mur X zmeur Rubus loganobaccus L.H. Bailey Hybridberry. In: Studia Universitatis Moldaviae. Nr.1 (101) 2017, p. 69-73.

3. Namiesnik J., Vearasilp K. et al. In vitro studies on the relationship between the antioxidant activities of some berry extracts and their binding properties to serum albumin. Applied Biochemistry and Biotechnology, 2014, v. 172, p. 2849-2865.

4. Slatnar A., Jakopic J. et al. The effect of bioactive compounds on in vitro and in vivo antioxidant activity of different berry juices. PLOS ONE, 2012, v. 7, p. 10. 